\title{
Journal of Anesthesia and Surgery
}

\section{Long-Term Follow-up of Malone Meatoplasty for Meatal Stenosis in Patients with Lichen Sclerosus}

\author{
Víctor Navalón-Monllor, Celia Ramada- Calaforra, Felipe Ordoño-Domínguez, Yoni Pallás-Costa, $\mathbf{M}^{\mathrm{a}}$ \\ Elisa Monllor-Peidro, Pedro Navalón-Verdejo*
}

Catholic University San Vicente Mártir. Valencia, Spain

*Corresponding author: Pedro Navalón Verdejo, Paseo Alameda 38- 2, 46023, Valencia, Email: pedronavalon@yahoo.com

\begin{abstract}
Objective: To show our experience in the treatment of meatal stenosis secondary to balanitis xerotica obliterans by the use of a dorsal meatoplasty technique.

Materials and methods: We have performed dorsal meatoplasty to 57 patients suffering from meatal stenosis caused by lichen sclerosus. In all cases the individuals were operated on under local anesthesia and following Malone's original technique: plasty through "inverted V" incision.

Results: In almost all the operated patients, we observed a significant improvement in urine flow and an excellent aesthetic result with very low incidence of disperse micturition. We have noted a high satisfaction rate by carrying out a survey. We didn't register any post-operative complication. In 2 patients $(3.5 \%)$ the stenosis reappeared and persisted during an average time of 39.5 months (range 6 - 130).

Conclusions: Dorsal meatoplasty with "inverted V" incision is an easily executable technique that can be performed under local anesthesia, avoids post-operative hypospadias and gives excellent aesthetic and functional results with low recurrence rate, which is why we hold the opinion that this procedure should be included in the daily practice of the urologist.
\end{abstract}

Received date: October 3, 2017

Accepted date: November 1, 2017

Published date: November 6, 2017

Citation: Navalón, P., et al. Long-Term Follow-up of Malone Meatoplasty for Meatal Stenosis in Patients with Lichen Sclerosus. (2017) J Anesth Surg 4(2): 121- 124.

DOI: $10.15436 / 2377-1364.17 .096$

Keywords: Lichen schlerosus; Balanitis xerotica obliterans; Meatal stenosis

\section{Introduction}

Urethral meatus stenosis can present itself in both genders, however more so in masculine. In men, it is usually caused by the inflammation of said meatus following circumcision, mainly in children, and constitutes the entity known as ammoniacal meatitis, which brings with itself scarring and growth of abnormal tissue, generally a thin layer of skin which obliterates the meatus ${ }^{[1]}$. In adults, it can be related to any inflammatory or infectious pathology of the urethra (both specific and non-specific), traumatisms (especially secondary to urethral instrumental manipulation) or be the result of failure of previous repairing of a hypospadias. In any case, the most frequent cause of this pathology in the adult patient is lichen sclerosus ${ }^{[2,3]}$.

A combination of topic steroids and antibiotics can help stabilize inflammation around the meatus. In this way, in patients whose meatus permits an acceptable urinary flow conservative therapy is justified. However, in patients who present a severe stenosis which provokes obstructive pathology, surgical correction is indicated ${ }^{[4]}$.

The "ideal meatoplasty" should not only consider functional aspects but also aesthetical. Then, not only should the obstruction be resolved permanently, but also a lineal meatus which allows an emission of urine with no dispersion of it must be provided.

The surgical treatment of this entity presents high recurrence rates, which implies an important repercussion in the patients' quality of life, which becomes diminished as a result of the multiple reinterventions ${ }^{[5]}$. A surgical alternative which has been recently described ${ }^{[6]}$ is the dorsal meatoplasty in "inverted V", which was successfully performed in our hospital. Its attained functional and aesthetical results are being prospectively evaluated and described in this article.

\section{Objectives}

The main objective of this study is to describe this technique for treatment of meatal stenosis secondary to balanitis xerotica obliterans. We also attempt to bring forward the excellent 
results, both aesthetic and functional obtained in the long term with this procedure.

\section{Patients and method}

Between January 2006 and December 2016, with previous approval of the ethical commitee of our institution, we have performed surgery on 57 patients with meatal stenosis secondary to balanits xerotica obliterans, using the "inverted V" dorsal meatoplasty, according to the original technique described by Malone. The mean age of our patients was 63 years old (ranging from 15 to 83 ).

According to their backgrounds, a total of 43 patients (75\%) were previously circumcised, $12(21 \%)$ followed a periodic autodilatation program, and another 15 (26\%) had a previous ventral meatoplasty.

As inclusion criteria, a severe meatal stenosis, and a diagnosis of balanitis xerotica obliterans (clinical or histopathological) were required. In this way, all the patients in the study were diagnosed with lichen sclerosus clinically, and in 40 of them $(70 \%)$ the disease was pathologically confirmed. All those patients who did not have a pure meatal stenosis were discarded, as in case of being the navicular fossa affected, we advise to perform a urethroplasty.

In all cases an uroflowmetry was done before and after the intervention (usually in the revision 6 months into post-operatory period), for which a Medical Measurement System (MMS) multicanal equipment was used (UP-2000 model). To measure the post mictional residue, we used a Toshiba ecograph with a 5 MegaHz convex abdominal transducer.

The mean long term surveillance period has been 39.5 months (range 6 - 130), being done on all the patients in the manner of an exhaustive interview about characteristics of the urinary flow as well as a careful clinical exploration opening up the new meatus so as to visualize the urethra. Also, in the revision carried out 6 months later, all the patients filled in a brief questionnaire concerning their degree of satisfaction with all the results of the intervention (details on Table 1).

Table 1: Obtained results in the patient's satisfaction questionnaire in regards to the procedure.

\begin{tabular}{|l|l|r|l|}
\hline \multicolumn{2}{|c|}{} & $\mathrm{N}^{\mathrm{o}}$ & $\%$ \\
\hline \multirow{4}{*}{$\begin{array}{l}\text { 1. Are you pleased with the } \\
\text { cosmetic appearance of your } \\
\text { penis after the operation? }\end{array}$} & Very happy & 35 & $61 \%$ \\
\cline { 2 - 4 } & Happy & 20 & $35 \%$ \\
\cline { 2 - 4 } & Unhappy & 2 & $4 \%$ \\
\cline { 2 - 4 } & Very unhappy & 0 & $0 \%$ \\
\hline \multirow{4}{*}{$\begin{array}{l}\text { 2. When you pass urine do you } \\
\text { spray? }\end{array}$} & Never & 32 & $56 \%$ \\
\cline { 2 - 4 } & Occasionally & 15 & $26 \%$ \\
\cline { 2 - 4 } & About half the time & 7 & $12 \%$ \\
\cline { 2 - 4 } & Usually & 3 & $5 \%$ \\
\cline { 2 - 4 } & Always & 0 & $0 \%$ \\
\hline \multirow{3}{*}{$\begin{array}{l}3 . \text { If you do spray when you } \\
\text { pass urine how bad is it? }\end{array}$} & Mild & 14 & $56 \%$ \\
\hline & Moderate & 9 & $36 \%$ \\
\hline & Severe & $8 \%$ \\
\hline
\end{tabular}

In all patients the surgical procedure was carried out following the next sequence: approximately one hour prior to the procedure, the patient applies a lidocaine and $50 \%$ prilocaine cream (EMLA cream), topically extended on all the surface of the penis. Infiltration of local anaesthetic in the body of the penis ( $2 \%$ lidocaine). Optionally a tourniquet can be applied in the base of the penis to minimize haemorrhage and ease the intervention, though lately we choose not to carry out this option. 2-4/0 nylon reference sutures are laid down in either side of the stenotic meatus. Minimal incision of the meatus on its ventral side, creating a small meatotomy so as to ensure the meatus does not become hypospadic (Figure 1A). Comprobation of the proximal urethra's indemnity with the introduction of a pin or a couple of centimetres of an 18 or $20 \mathrm{Ch}$ probe (Figure 1B). In case the stenosis extended significantly in the navicular fossa, said technique would fail, for which it would be necessary to carry out another type of urethroplasty. Interrupted polygalactin $4 / 0$ to $6 / 0$ suture oposing the urethral epithelium to that of the gland. Another meatotomy in the dorsal facet, deeper than the ventral is done, attaining a sufficient opening of the meatus (Figure 1C), followed by a $4 / 0$ to $6 / 0$ poligalactin interrupted suture, opposing the urethral epithelium to that of the gland (Figure 1D). This manouvre widens the meatus, but attributes an antiaesthetic appearance to it. Relaxing gland incision in an "inverted V" shape, with the base of the $\mathrm{V}$ close to the proximal limit of the dorsal meatotomy (Figure 1D), later liberating the $\mathrm{V}$ incision borders using acute dissection as means to do so. Continuous polygalactin $5 / 0$ to $7 / 0$ suture opposing the internal borders of the $\mathrm{V}$ incision, forming the superior portion of the new meatus (Figure 1E). Suture of simple polygalactin $4 / 0$ to $6 / 0$ stitches of the external borders of the $\mathrm{V}$ incisión (Figure $1 \mathrm{~F}$ ), giving as a result a slit-like meatus with an optimal caliber (Figure 1H).

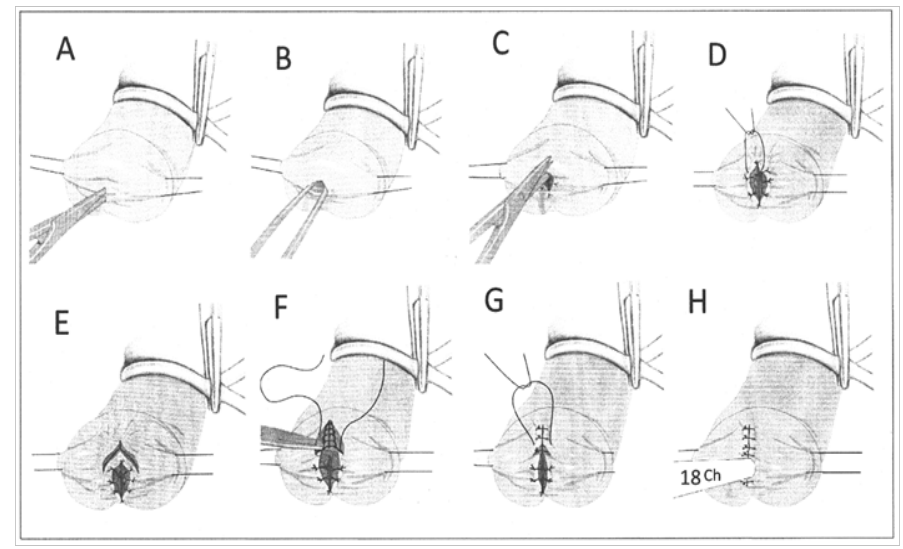

Figure 1: Surgical sequence according to Malone's meatoplasty.

The statistical analysis of the results was done using SPSS 19 (SPSS Inc., Chicago, IL). When a comparison between the means was necessary we applied the t-Student test, considering statistical significance when $\mathrm{p}<0.05$. In case of needing to compare qualitative aspects, we used $\chi 2$ test.

\section{Results}

All patients had surgery performed on them under local anaesthesia and ambulatory regime. In any case performing another surgery or additional sedo-anelgesia was required. Every patient both objectively and subjectively recovered their urinary flow, noticing a significant improvement during the flowmetry where the mean preoperatory Qmax (flow peak) was $7.2 \pm 2.9$ $\mathrm{cc} / \mathrm{s}$ and $16.4 \pm 3.7 \mathrm{cc} / \mathrm{s}$ in postoperatory. There was also a statistically significant improvement in the post mictional residue 
determinations, which were $285 \pm 93$ cc before the operation, and $80 \pm 38 \mathrm{cc}$ after the operation.

All the patients answered the satisfaction degree questionnaire which included both functional and aesthetic results obtained with the procedure. Data are resumed in Table 1.

They were followed during a mean time of 39.5 months (range 6 - 130). We noticed recurrence of the stenosis in 2 patients $(3.5 \%)$, where one of them had surgery performed on him again and the other one developed a submeatal stenosis 5 years after the surgery. He is currently waiting for a distal urethroplasty with a buccal mucosa graft. 32 patients $(56 \%)$ did not inform of a disperse urinary flow and only 2 of them manifested having a disturbance which had an impact on their lives. The other 23 patients had a very small dispersion of their micturition and it did not entrail any significant trouble for the patient (Table 1).

\section{Discussion}

Multiple techniques were described for urethral stenosis treatment related to lichen sclerosus, particularly those using extragenital skin or buccal mucosa that are thought to correct lesions extending to the navicular fossa ${ }^{[7]}$. However, very few studies referring to the treatment of pure meatus lesions have been carried out, but even if they represent a less important pathology because of their small extension, they are still much more frequent.

Although meatal stenosis related to lichen sclerosus is a less severe condition than this same pathology affecting the urethra, it does not mean it represents an inferiorly dangerous entity, as it can give rise to serious complications such as urinary infections or chronic urine retention rarely associated to renal insufficency, which is why meatal stenosis should not be considered as a trivial pathology ${ }^{[8]}$.

A sub-meatal urethral stenosis with normal external meatus can have different aethiologies including infection and urological instrumentation, especially after a prostate transurethral resection ${ }^{[9]}$ However, pure meatal stenosis (even when the stenosis is wide enough to include the navicular fossa) is more frequently observed associated to lichen sclerosus even if it has also been found in circumcised patients because of a previous phimosis no matter if the surgery was performed for religious, cultural or hygienic reasons ${ }^{[10]}$.

Moreover, the existing literature on the subject provides the doctor trying to treat this pathology with a confusing selection of therapeutic options because such publications include patients with pure meatal stenosis, meatal stenosis which extends to the distal urethra, sub-meatal stenosis with a normal meatus and any type of narrowness whichever may be the aethiology ${ }^{[11]}$. This is why in patients suffering from lichen sclerosus and presenting a distal urethral stenosis that involves the meatus and the navicular fossa, it has been proven that urethroplasty with buccal mucosa graft offers better results than the local skin graft technique (a higher recurrence rate has been noticed when using genital skin $)^{[12]}$. Nevertheless, when stenosis is confined to the meatus, urethroplasty is usually not justified, in fact most of the time we use less complex techniques even if the results obtained are not as satisfactory as expected. Meatal dilation is then, related to a high recurrence rate which frequently requires continuous auto-dilatation to maintain the meatu's caliber. Equally so, the ventral meatotomy usually gives rise to a hypospadic meatus, particularly if the stenosis was severe, or if the meatus was already in a ventral position within the gland, this in itself associating with a high recurrence rate ${ }^{[13-16]}$. On the contrary, dorsal meatotomy provides an increased opening of the meatus than that performed ventrally, but due to the higher thickness of the corpus spongiosum in the dorsal face of the gland, the suture stitches necessary to oppose the borders give rise to a very antiaesthetical meatus. However the relaxing incision "in inverted V" we describe allows the creation of a lineal and optimally cosmetic meatus.

A classic variation of the meatoplasty, described and made widely known by Blandy and Tresider ${ }^{[17]}$, consists of a ventral flap, however with the disadvantage of leading to a hypospadic meatus, and with this a high tendency of dispersing the flow; also, as it happens with all local genital meatoplasties, the flap, with time, becomes surrounded in lichen sclerosus and it is the norm for a recurrence to occur ${ }^{[18-20]}$. The posterior modification proposed by De Sy ${ }^{[21]}$ can improve the aesthetics, but as the approach is also ventral, it becomes a poorly adequate technique for a ventrally localised meatus.

Another proposed therapeutical method was circumferential fotovaporization of the meatus using carbon dioxide $\operatorname{laser}^{[22]}$, but as all the other procedures above described, it does not fulfill the "ideal meatoplasty" criteria, which apart from permanently solving the obstruction, must proportionate a lineal meatus in the end of the gland which does not disperse the urine flow. All of these premises are achieved using the technique hereby exposed. Actually, we have had a very low recurrence rate, being $96 \%$ of patients bereft of recurrence during the mean surveillance time of 3.3 years (ranging from 6 months to 11 years). Equally, according to the aesthetic result, practically all of our patients $(96 \%)$ were satisfied or very satisfied with the achieved cosmetic appearance, including the fact that the dorsal scar was barely perceptible.

The controversy raised in the literature in regards to the convenience of performing a postectomy in the case that it had not been done previously. Depasquale and cols ${ }^{[12]}$ have demonstrated that circumcision alone is capable of halting the lichen sclerosus' progression in $92 \%$ of patients. Therefore, even though we do not consider it compulsory, even in those cases where lichen sclerosus is but perimeatal with no clinical signs of prepuce affection, we do advise it be done due to its stabilizing effect on lichen sclerosus, thus diminishing the probability of later affection of the prepuce due to the disease ${ }^{[23,24]}$.

On the other hand, it is known that alteration in the morphology of the meatus or the navicular fossa is usually translated into an establishment of urinary flow dispersions, giving rise to "spray micturition", as the existente of a uniform urinary flow, bereft of turbulences, depends on the urethra's and the meatus' shape. Thereby, it has been confirmed in flow dynamics studies, whose scientific fundaments were firstly reported by Geoffrey Taylor in the Royal Society in $1960^{[25]}$, where the change from a cylindrical tube to a lineal exit seems to be crucial for the fluid's current to be free from turbulences (Figure 2). Consequently, it seems to be that all meatoplasty technique which expects to attain a uniform urinary flow must attempt to create a lineal meatus structure. In this way, the majority of our pations presented a dispersion free flow, and when there was flow, usually this was a scarce quantity which minimally disturbed the patient, as shown in Table 1. 


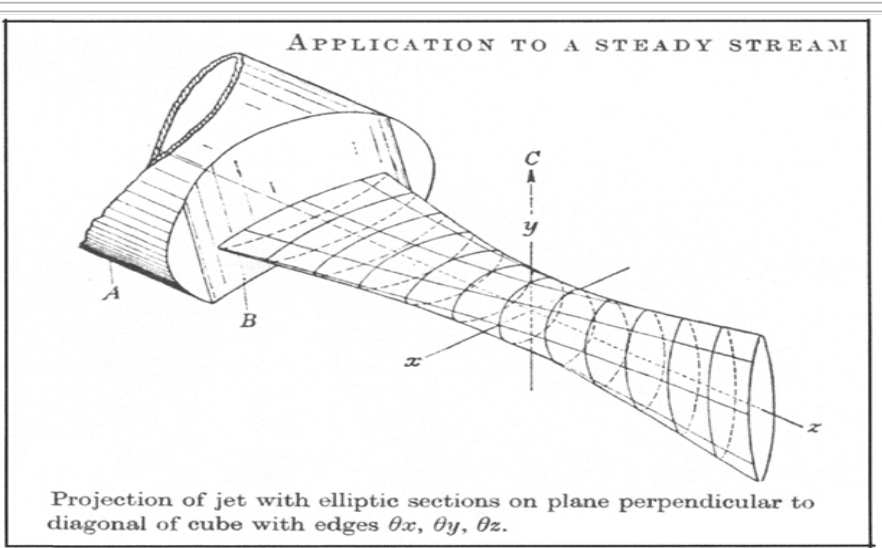

Figure 2: Scientifical fundaments of fluid dynamics through a lineal exit described by Geoffrey Taylor in the Royal Society(1960).

We believe the procedure described in this article is easily reproductible in any urology service, it does not require a complex infrastructure and it ostensibly improves the functional and aesthetic results of meatoplasties.

\section{Conclusion}

Dorsal "inverted V" meatoplasty is a technique easily carried out which is possible to perform under local anaesthesia, prevents the appearance of postsurgical hypospadias delivers excellent functional and aesthetic results, and has a low recurrence rate, therefore we consider that it must be included in urologists' habitual repertoire.

\section{References}

1. Calleja, E., Hernández, A.E., Marhuenda, C. Balanitis xerótica obliterante, patología infradiagnosticada de relevancia clínica. (2015) Cir Pediatr 28: 133- 136.

Pubmed | Crossref $\mid$ Others

2. Jordan, G.H., McCammon, K.A. Surgery of the Penis and Urethra (2012) United States of America Elsevier Saunders 964-1008.

Pubmed $\mid$ Crossref $\mid$ Others

3. Köhn, F.M., Schultheiss, D., Krämer Schultheiss, K. Dermatological diseases of the external male genitalia. (2016) Urologe A 55(6): 829842.

Pubmed | Crossref | Others

4. Pugliese, J.M., Morey, A.F., Peterson, A.C. Lichen sclerosus: Review of the literature and current recommendations for management. (2007) J Urol 178(6): 2268-2276.

Pubmed | Crossref | Others

5. Navalón, P., Pallás, Y., Juan, J., et al. La meatoplastia dorsal para el tratamiento de la estenosis de meato en pacientes con balanitis xerótica obliterante. (2007) Arch Esp Urol 60(1): 156- 160.

Pubmed $\mid$ Crossref $\mid$ Others

6. Malone, P. "A new technique for meatal stenosis in patients with lichen sclerosus". (2004) J Urol 172(3): 949- 952.

Pubmed | Crossref | Others

7. Nikolavsky, D., Abouelleil, M., Daneshvar, M. Transurethral ventral buccal mucosa graft inlay urethroplasty for reconstruction of fossa navicularis and distal urethral strictures: surgical technique and preliminary results. (2016) Int Urol Nephrol 48(11): 1823- 1829.

Pubmed $\mid$ Crossref $\mid$ Others

8. Sandler, G., Patrick, E., Cass, D. Long standing balanitis xerotica obliterans resulting in renal impairment in a child. (2008) Pediatr Surg Int 24(8): 961-964.

Pubmed | Crossref | Others
9. Treiyer, A., Anheuser, P., Reisch, B., et al. Tratamiento de la estrechez del meato uretral por balanitis xerótica obliterante: resultados a largo plazo empleando meatoplastia de Malone. (2011) Actas Urol Esp 35(8): 494- 498.

Pubmed $\mid$ Crossref $\mid$ Others

10. Ceylan, K., Burhan, K., Yilmaz, Y., et al. Severe complications of circumcision: an analysis of 48 cases. (2007) J Paediatr Urol 3(1): 3235.

\section{Pubmed | Crossref | Others}

11. Meeks, J.J., Barbagli, G., Mehdiratta, N., et al. Distal urethroplasty for isolated fossa navicularis and meatal strictures. (2012) BJU Int 109(4): 616-619.

Pubmed | Crossref | Others

12. Depasquale, I., Park, A.J., Bracka, A. The treatment of balanitis xerotica obliterans. (2000) BJU Int 86(4): 459-465.

Pubmed $\mid$ Crossref $\mid$ Others

13. Kulkarni, S., Barbagli, G., Kirpekar, D., et al. Lichen sclerosus of the male genitalia and urethra: Surgical options and results in a multicenter international experience with 215 patients. (2009) Eur Urol 55: 945-956.

Pubmed | Crossref | Others

14. Fistarol, S.K., Itin, P.H. Diagnosis and treatment of lichen sclerosus: an update. (2013) Am J Clin Dermatol 14: 27-47.

Pubmed | Crossref | Others

15. Powell, J., Robson, A., Cranston, D., et al. High incidence of lichen sclerosus in patients with squamous cell carcinoma of the penis. (2001) Br J Dermatol 145(1): 85-89.

Pubmed | Crossref | Others

16. Gutiérrez, M., Vicente, F.J., López, J.L. Lichen sclerosus and squamous cell carcinoma. (2012) Actas DermoSifiliogr Engl Ed 103(1): 21 28.

Pubmed | Crossref $\mid$ Others

17. Blandy, J.P., Tresidder, G.C. Meatoplasty. (1967) Br J Urol 39(5): 633-635.

Pubmed $\mid$ Crossref $\mid$ Others

18. Celis, S., Reed, F., Murphy, F., et al. Balanitis xerotica obliterans in children and adolescents: a literature review and clinical series. (2014)

J Pediatr Urol 10(1): 34-39.

Pubmed | Crossref | Others

19. Naji, H., Jawad, E., Ahmed, H.A., et al. Histopathological examination of the prepuce after circumcision: Is it a waste of resources? (2013) Afr J Paediatr Surg 10(2): 164-166.

Pubmed | Crossref | Others

20. Lewis, F.M. Vulval disease from 1800 s to the new millennium. (2002) J Cutan Med Surg 6(4): 340-344

Pubmed | Crossref | Others

21. De Sy, W.A. Aesthetic repair of meatal stricture. (1984) J Urol 132(4): 678-680.

Pubmed | Crossref $\mid$ Others

22. Windahl, T. Is carbon dioxide laser treatment of lichen sclerosus effective in the longrun? (2006) Scand J Urol Nephrol 40(3): 208-211. Pubmed | Crossref | Others

23. Fiala, R., Vrtal, R., Zenisek, J., et al. Ventral prepucial flap meatoplasty in the treatment of distal urethral male strictures. (2003) European Urology 43(6): 686-688.

Pubmed | Crossref | Others

24. Acimovic, M., Milojevic, B., Milosavljevic, M., et al. Primary dorsal buccal mucosa graft urethroplasty for anterior urethral strictures in patients with lichen sclerosus. (2016) Int Urol Nephrol 48(4): 541-545. Pubmed | Crossref | Others

25. Taylor, G. Formation of thin flat sheets of water. (1960) Proc R Soc London 259: 1-17.

Pubmed | Crossref | Others 